\title{
Virtù, Fortuna, and Statecraft: A Dialectical analysis of Machiavelli
}

\section{Anthony Lawrence A. Borja}

\begin{abstract}
The issue of statecraft is central to the works of Machiavelli, and his primary contribution to contemporary practice and theorizing is an exposition of the inevitable complexities behind this human endeavor. States rise and fall because of failures in leadership tied with the moving contours of the political arena itself. Key to Machiavelli's analysis of statecraft is the internal relations between Virtù and Fortuna. I intend to show that Machiavelli's contribution to the modern notion of state-building is not only an exposition of the innards of court politics, but also a development of the classical notion of virtù-Fortuna into a vital component that gave statecraft and, to an extent, politics in general its spirit of eternal motion. Machiavelli paved the way for a modern notion of statecraft by exposing the primary problem that gives it meaning through its inherent irresolvability-statecraft as determined by the convergence of virtù as a conscious effort with the basket of constantly moving objective factors we call Fortuna. Specifically, I argue that virtù and its dimensions seek to penetrate Fortuna and expose its concrete components, hence, making these factors recognizable, understandable, predictable, and eventually, vulnerable to acts of establishing and sustaining control.
\end{abstract}

Keywords: Althusser, Machiavelli, leadership, state-building

7 he issue of statecraft is central to the works of Machiavelli and his primary contribution to contemporary practice and theorizing is an exposition of the inevitable complexities behind this human endeavor. States rise and fall because of failures in leadership tied with the moving contours of the political arena itself. Simply put, a leader can fail without destroying his/her state, or he/she can succeed where others failed. Key to Machiavelli's analysis of statecraft is the internal relations between Virtù and Fortuna. However, there is a lack of an organized schema that can explain the different dimensions of the internal relationship between Virtù and Fortuna. Formerly, an attempt was made by Wood to posit a reconstruction of

(c) 2016 Anthony Lawrence A. Borja

http://www.kritike.org/journal/issue 18/borja june2016.pdf

ISSN 1908-7330

(cc) BY-NC-ND 
Machiavelli's virtù through two thrusts, namely, its relationship with necessity and with war. ${ }^{1}$ He illustrated that, for Machiavelli, necessity produces virtù through a cycle facilitated by the contradiction between discipline as a keystone for virtù given by the necessities of survival, and idleness/luxury as a result of a successful transition from stability to wealth. ${ }^{2}$ Concerning war and the nature of virtù, Wood argued that reflective of Machiavelli's usage of ancient warrior-statesmen as illustrations, virtù "therefore, is a set of qualities, or a pattern of behavior most distinctively exhibited under what may be described as battlefield conditions" ${ }^{3}$ in the context of actual warfare or politics. What I would like to note from these two thrusts is that virtù, when taken in isolation, often leads to fragmentary reconstructions emphasizing some aspects at the expense of others. Moreover, in relation to Wood, I note that, for Newell, disorder marks Machiavelli's originality in comparison to Christian theology and Humanism. For him, Machiavelli saw disorder as fundamental to an understanding and execution of statecraft, that is, statesmen must realize that Fortuna's unreliability should be harnessed through freeing selfish impulses and acting in accordance, not to utopian delusions but to the reality of political disorder. ${ }^{4}$

Simply put, disorder, instability, and unpredictability are necessary factors in providing a more nuanced understanding of this concept's passage through Machiavelli. To elaborate, Machiavelli's virtù, when understood from a relational perspective, steers away from an atomistic conception of individual will; one's virtù is both insufficient in the constant struggle for power and does not necessarily entail the abandonment of collective activities as means of satisfying individual interests. Specifically, Fortuna as the primary external factor facing virtù can be understood as a key in achieving a more holistic understanding of Machiavelli's framework.

Though insightful, Wood fell short in relating Fortuna as another important concept utilized by Machiavelli in his analysis of virtù. For this reason, I will extend Wood's relational analysis towards virtù and Fortuna as two central concepts within The Prince and the Discourses on Livy. Furthermore, this goal is necessitated by later analyses that gave due weight to the interaction between virtù and Fortuna in efforts to better understand Machiavelli's contribution to the modern concept of politics. ${ }^{5}$ Hence, I will

\footnotetext{
${ }^{1}$ Neal Wood, "Machiavelli's concept of Virtù Reconsidered," in Political Studies, 15 (1967), 160, 167-70.

${ }^{2}$ Ibid., 166-8.

${ }^{3}$ Ibid., 171.

4 W.R. Newell, "How Original Is Machiavelli? A Consideration of Skinner's Interpretation of Virtue and Fortune," in Political Theory, 15 (1987), 628-9.

${ }^{5} \mathrm{I}$ 'm referring to the following: Louis Althusser, Machiavelli and Us, trans. by Gregory Elliot (London: Verso, 1999), 3-111; John Greville Agard Pocock, The Machiavellian Moment:
} 


\section{4 \\ VIRTÙ, FORTUNA, AND STATECRAFT}

try to fabricate a framework for the internal relationship between Machiavelli's virtù and Fortuna. In trying to achieve this, I will pursue the following goals, namely, to illustrate (1) that the varied dimensions of virtù could be organized and synthesized in relation to Fortuna, and (2) that Machiavelli's notion of statecraft is founded on the eternal struggle caused by the internal relations between virtù and Fortuna. For both objectives, I argue that in exposing the concrete bases of Machiavelli's Fortuna, I could provide a more nuanced portrait of virtù and its dimensions; that is, when used in both offence and defense, it seeks to penetrate Fortuna and expose its concrete components, hence, making these factors recognizable, understandable, predictable, and eventually, vulnerable to acts of establishing and sustaining control. In line with these, I intend to show that Machiavelli's contribution to the modern notion of state-building is not only an exposition of the innards of court politics, but also a development of the classical notion of virtù-Fortuna into a vital component that gave statecraft and, to an extent, politics in general its spirit of eternal motion. By juxtaposing the absence of guarantees and absolute security with the urgency and principles of achieving a semblance of these conditions, Machiavelli paved the way for a modern notion of statecraft by exposing the primary problem that gives it meaning through its inherent irresolvability - statecraft as determined by the convergence of virtù as a conscious effort with the basket of constantly moving objective factors we call Fortuna. Machiavelli's contribution stands firm as the problems he exposed remain and will probably remain unresolved.

\section{Dialectics in Machiavelli}

For a dialectical analysis of Machiavelli, we turn to Althusser who illustrated in Machiavelli and Us that Machiavelli's importance is based on his analytical approach bent on dissecting political conjunctures and placing political practice within such a framework deprived of any source of guarantee and defined by over-determination; that is, the image of the political arena that can be deduced from Machiavelli's works is defined by the absence of linear causality and the primacy of constant change and struggle. Focusing on Althusser's schema, I would like to note three basic thrusts, namely, his arguments on Machiavelli as a theorist of the conjuncture, his reconstruction of Machiavelli's arguments on history, and lastly, his discussion on the interplay between Fortuna and Virtù. Firstly, for Althusser, ${ }^{6}$ Machiavelli was the first to think within and of the historico-political conjuncture that faced him. To be specific, Machiavelli's approach to the

Florentine Political Thought and the Atlantic Republican Tradition (Princeton: Princeton University Press, 1975), 156-218.

${ }^{6}$ Althusser, Machiavelli, 17-9.

(C) 2016 Anthony Lawrence A. Borja

http://www.kritike.org/journal/issue 18/borja june2016.pdf

ISSN 1908-7330

(c) ) BY-NC-ND 
question of statecraft was to grasp the complexities facing it as based upon the confrontation and constant struggle between the results of human forces.

Second, in extracting Machiavelli's theoretical framework and comparative approach, Althusser ${ }^{7}$ synthesized the former's general theory on history into three interacting theses, namely, the immutability of human and natural things, the continual motion of human affairs, ${ }^{8}$ and the cyclicality of human affairs and the typology of governments driven to change by the wheel of Fortune (i.e., the inevitability of corruption and the de/centralization of power). ${ }^{9}$ For the first two theses, he argued that these were Machiavelli's philosophical assumptions that allowed him to conduct comparative analysis; immutability allowed Machiavelli to isolate constants among cases while the assumption on constancy of change facilitated the identification of variations. ${ }^{10}$ Furthermore, while the first two theses pinpointed the contradiction that Machiavelli stumbled upon and recognized in his analysis of both the political arena and political practice, the third thesis was the product of the contradiction between the first two that Machiavelli accomplished by transforming the classical typology of governments into a cycle of governments. This cycle is based on a pattern defined by an incumbent's descent into corruption and the contraction or expansion of the number of rulers (i.e., distribution of power). Now from these theses, Althusser extracted Machiavelli's fourth thesis or his political position. For him, Machiavelli was concerned with a state that transcends the cyclicality of government so as to ensure its durability and endurance ${ }^{11}$; that is, the problem of a state's duration (specifically that of achieving stability and order in the omnipresence of external instabilities and disorders, and internal threats to what was achieved) was central to Machiavelli's discussion on the cyclicality of history as the product of the constancy of change and man's will and struggle to survive or benefit from it. ${ }^{12}$ Simply put, Machiavelli wanted a state that, through virtù, will endure despite the constancy of change in its government, that is, a state similar to Rome that endured despite the drastic transitions that took place in it. ${ }^{13}$

${ }^{7}$ Ibid., 34-6.

${ }^{8}$ On the link between audacity and Fortuna's inherent uncertainty, see Timothy J. Lukes, "Fortune Comes of Age in Machiavelli's Literary Works," in Sixteenth Century Journal, 11 (1980), 33-50.

${ }^{9}$ On Machiavelli's adaptation of Polybius' notion of the cyclicality of the Aristotelian typology of governments, see Althusser, Machiavelli, 36-9.

${ }^{10}$ Ibid., 34-5.

${ }^{11}$ Ibid., 40-2.

${ }^{12}$ Ibid., 41-2

${ }^{13}$ I note that it is within the reason of state that Machiavelli's arguments on state virtù was expounded. For a review of the literature on Machiavelli's contribution to this theoretical trend, see Peter Breiner, "Machiavelli's 'New Prince' and the Primordial Moment of Acquisition," in Political Theory, 36 (2008), 66-92; Harvey C. Mansfield, "On the Impersonality of 
Althusser ended his discussion by positing Machiavelli's new prince as the bearer of virtù as the capacity to harness change (i.e., Fortuna) in establishing an enduring state. In relation to this, he discussed three possibilities regarding the engagement between virtù (as the subjective conditions) and Fortuna (as the objective conditions of the conjuncture) in the context of Machiavelli's new prince. ${ }^{14}$ First is a correspondence wherein the material of favorable Fortuna finds a proper form in the virtù of an individual, hence, allowing the establishment of a durable state. Second is a noncorrespondence wherein the absence of virtù gives Fortuna a free hand to take and/or give an individual power. Lastly is a deferred correspondence wherein the virtù of an individual could allow him/her to reclaim the power that Fortuna might take. Regarding the latter, I would like to note that, for Althusser, virtù draws its distinction from its inherent goal of mastering Fortuna, that is, of transforming the material of Fortuna, specifically of political conjunctions into the durability of a state by laying its foundations through virtù in correspondence or non-correspondence with Fortuna. In summary, Althusser opened two intertwined opportunities for a dialectical reconstruction of Machiavelli's framework, namely, the concrete factors behind Fortuna and the inner-relatedness of virtù and Fortuna. ${ }^{15}$ However, his analysis was limited by the fact that to answer how Fortuna manifests itself does not completely answer what Fortuna is; a question, I believe, was already answered implicitly by Machiavelli. For this reason, he was able not only to dissect virtù in the proper context of a concretized sense of Fortuna, but also to herald a modern conceptualization of statecraft that exposed both the social bases of change and cyclicality, and its dynamic root in the struggle between virtù and Fortuna. Hence, at the point where Althusser failed to specify Fortuna's concrete foundations, my reconstruction of Machiavelli would come in to further shed light upon the roots of its engagement and internal relations with virtù. Thus, I will illustrate that while virtù emerges out of the political conditions shaped by Fortuna as a set of internalized practices and principles, the latter's human component is founded on the interactions between those pursuing their own interests through their expression or lack of virtù; Fortuna is as human as virtù.

the Modern State: A Comment on Machiavelli's Use of Stato," in The American Political Science Review, 77 (1983), 849-57; Maurizio Viroli, "The Revolution in the Concept of Politics," in Political Theory, 20 (1992), 473-495.

${ }^{14}$ Althusser, Machiavelli, 74-6.

${ }^{15}$ I note that for the following authors, the internal relationship between virtù and Fortuna could be defined as the latter providing conditions of chance, disorder, and instability for the former's expression as discipline, audacity, improvisation, and innovation: Newell, "How Original Is Machiavelli?," 628-9; Charles D. Tarlton, "Azioni in modo l'una dall'altra: action for action's sake in Machiavelli's The Prince," in History of European Ideas, 29 (2003), 126-7, 136; Wood, "Virtù Reconsidered," 169-70.

(C) 2016 Anthony Lawrence A. Borja

http://www.kritike.org/journal/issue 18/borja june2016.pdf

ISSN 1908-7330

(c) $)$ BY-NC-ND 


\section{On Virtù and Fortuna: A Conceptual Framework}

Aligned with the literature reviewed, my analysis will have two dimensions. First, I will illustrate how Machiavelli saw the struggle between virtù and Fortuna as a form of socio-political relation. Second, through Machiavelli's political psychology, ${ }^{16}$ I would further shed light on the internal relations between virtù and Fortuna by fabricating a framework categorizing and synthesizing the different dimensions of virtù that could be found in Machiavelli's discussions on princes and citizens (on principalities and republics). Regarding the first level of my analysis, I begin by distinguishing Fortuna from necessity, with the former subsuming the latter as its bridge to virtù. Virtù as acting towards Fortuna is about recognizing and reacting to necessity; that is, virtù could either be an anticipation of Fortuna by foreseeing future necessities or an adaptive reaction to it. The absence of virtù causes a subject to be solely driven by necessity without understanding and recognizing Fortuna as the factor and logic behind it (i.e., the constancy of change). ${ }^{17}$ But what is it that must be recognized?

Here we arrive at my contention that Fortuna, for Machiavelli, consists of both human and natural factors that are from a subject's perspective uncontrollable and unpredictable. This is aligned with the current literature that takes Fortuna as an external factor facing virtù and an elaboration of Kocis' argument that Fortuna is mere literary or explanatory device. ${ }^{18}$ Though I agree with the latter's premises that led to such a conclusion $^{19}$ (specifically his illustration that it served the purpose of establishing a notion of the world as being vulnerable to human exertions), I contend, on the contrary, that for Machiavelli, Fortuna is an important concept that referred to concrete factors. This is primarily based on my observation that his discussions on Fortuna in both The Prince and the Discourses, as well as in some letters, ${ }^{20}$ are situated before or after an examination of the activities of others directly related to the subject. I argue that Machiavelli's belief on Fortuna is directed at the unpredictability and uncontrollability of the

\footnotetext{
${ }^{16}$ Markus Fischer, "Machiavelli's Political Psychology," in The Review of Politics, 59 (1997), 789-829.

17 Niccolò Machiavelli, The Prince, $2^{\text {nd }}$ ed., trans. by Harvey C. Mansfield (Chicago: Chicago University Press, 1998), 96-97. Hereafter cited as Prince.

${ }^{18}$ Robert A. Kocis, Machiavelli Redeemed: Retrieving his Humanist Perspectives on Equality, Power, and Glory (Bethlehem: Lehigh University Press, 1998), 51.

${ }^{19} \mathrm{Ibid}$., 46-52 for details on Machiavelli's usage of Fortuna as a concept.

${ }^{20}$ Niccolò Machiavelli, The Letters of Machiavelli: A Selection, trans. by Allan Gilbert (Chicago: The University of Chicago Press, 1961), 97-9, 108-20. From this collection of Machiavelli's letters, I am referring to the following letters: No. 116 for Piero Soderini, Nos. 124, 128 for Francesco Vettori.
}

(c) 2016 Anthony Lawrence A. Borja

http://www.kritike.org/journal/issue 18/borja june2016.pdf

ISSN 1908-7330

(cc) BY-NC-ND 
cumulative effects of external factors. ${ }^{21}$ Focusing on its human component, two arguments made by Machiavelli can illustrate my contention through Fortuna's capacity to give opportunities for the realization of virtù. First, for Machiavelli, Fortuna could favor a prince by creating enemies that he could crush, thus, elevating his status. Hence, in harnessing Fortuna, Machiavelli stated "that a wise prince, when he has the opportunity for it, should astutely nourish some enmity so that when he has crushed it, his greatness emerges the more from it." 22

Second, in the Discourses, Machiavelli argued that virtù in its most general sense has a quality of excellence and strength that passes from people to people, from one state to another. He illustrated that in the interplay between virtù and Fortuna, the dissolution of one's virtù is the harbinger of favorable Fortuna for another. ${ }^{23}$ This other (ex. neighbors of a falling state), in facing the latter, is given the opportunity to internalize virtù, thus, transferring to a new bearer who succeeds in internalizing and expressing it to harness the favorable Fortuna. Simply put, the degradation of one is the favorable Fortuna of another; the idleness of the Medes, the disunity of the Athenians, and the slavery of the Hebrews all allowed their respective princes in such conjunctions to emerge as anti-thetical entities that internalized what was lost by their targets. Hence, I believe that for Machiavelli, Cyrus became the epitome of the vigor lost by the Medes, Theseus sought the unity of a divided people, and Moses embodied the autonomy and nationhood lost by the Hebrews under captivity. ${ }^{24}$

Regarding Fortuna's malevolence, I argue that in relating Chapters 24, 25, and 26 of The Prince with each other, Machiavelli related the fall of the princes of Italy with their lack of virtù or the inability to at least resist or alleviate the damages of Fortuna embodied by the constant intrusion of foreign powers tied and facilitated by their dependence on mercenaries (two factors that aggravated the volatility of political and military affairs). ${ }^{25}$ Thus, when Machiavelli urged the House of Medici to lead Italy ${ }^{26}$ he was referring not only to the political positions held by that family, but also to the conjunction of external conditions calling for their leadership, that is, in Althusserian terms, the possibility of a correspondence between Fortuna and virtù.

${ }^{21}$ Niccolò Machiavelli, Discourses on Livy, trans. by Harvey C. Mansfield (Chicago: Chicago University Press, 1996), 198-199. Hereafter cited as Discourses.

${ }_{22}$ Machiavelli, Prince, 85.

${ }^{23}$ Machiavelli, Discourses, 123-125.

${ }^{24}$ Machiavelli, Prince, 22-24.

${ }^{25}$ Ibid., 49, 96-97, 104.

${ }^{26}$ Ibid., 102.

(C) 2016 Anthony Lawrence A. Borja

http://www.kritike.org/journal/issue 18/borja june2016.pdf

ISSN 1908-7330

(c) BY-NC-ND 
From these examples I argue that, for Machiavelli, the concept of Fortuna subsumes all these concrete and interacting factors under the general characteristics of uncontrollability and unpredictability, hence, serving as a vital concept defining the attributes of the socio-political environment that a subject must deal with. At an aggregate level, these concrete factors for Machiavelli, specifically their deliberate activities (including other expressions of virtù), their interaction with each other, and their subsequent impact on a subject could be summed up with the notions of instability and insecurity. Fortuna, simply, is the weaving of the activities and characteristics of external factors (both human and natural) that in the end will actively subsume the subject as part of its web. This notion of Fortuna's ontological primacy over virtù was deduced from the eternity of Fortuna's movement against the mortality of man. To be specific, when taken as an aggregate in motion, the concrete factors behind Fortuna surpass the temporality of the same factors when taken as particulars. ${ }^{27}$ In line with this, I argue that virtù for Machiavelli involves an effort to understand the patterns weaved before by studying history, and by unweaving a specific conjunction in the web by deducing what is deliberate (what was and what could be conducted by others), and acting accordingly either as a response or an anticipation of what was exposed.

Regarding virtù, I will now present a conceptual framework based on the schema proposed by Fischer in his extraction of the political psychology in Machiavelli's work. Fischer argued that two categories could be deduced to define the character of the Machiavellian man, namely, necessary or natural properties, and accidental or contingent attributes. ${ }^{28}$ The former was defined as qualities inherent in men, which includes the following: (1) animo as the motivation or energy behind actions, (2) the mind, which as a guide for our actions includes memory, ingenuity, and imagination, (3) virtù that refers to the higher degrees of the first two qualities, (4) man's sense of individuality, (5) desires, (6) humors, and lastly (7) ambition and license. ${ }^{29}$ Furthermore, for Machiavelli, variations in the degrees and particulars of these qualities would, on one hand, account for the different ideal types of political actors ranging from the vulgar to the prince and, on the other, contribute to the success or failure of a political entity. Concerning accidental attributes, Fischer argued that these are acquired qualities that take external forces into account (ex. the imposition of an other's will). ${ }^{30}$ This category refers to the different habits that Machiavelli took into account in relation to the issue of a collective's virtù (i.e., cooperative habit) and eventual

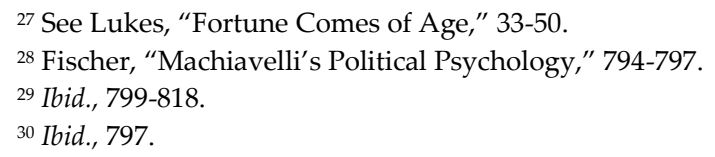


corruption. This issue will be pursued by my analysis but, in summary, Fischer provided a framework that could be utilized to give a systematic exposition of the virtù-Fortuna issue at the level of the individual, a level that Machiavelli shared in The Prince.

For the purposes of this paper, I found it necessary to distinguish virtù from a subject's inherent characteristics in order for the former to be internally related with Fortuna without dragging the complexities of the subject with it. I argue that, contrary to Fischer's inclusion of virtù as an internal and necessary quality, virtù could be considered as a set of principles and practices (a mentality or mind-set, and behavior) that are internalized in accordance to the demands of an external factor (i.e. Fortuna) and a subject's inherent attributes; the former, as would be discussed later on, determines what should be internalized, while the latter determines whether the internalization will be successful. One illustration of this distinction was Machiavelli's discussion on the manner of choosing ministers and handling court politics (on advice and flattery) wherein he distinguished between a ruler's intelligence and two principles, namely, a balance between autonomy and openness to advice in making decisions, and keeping ministers and courtiers under one's control (specifically for ministers whose interests must be solely for service to their prince). ${ }^{31}$

In summary, Machiavelli portrayed intellectual capacity as a factor that will determine whether such principles will be effectively internalized and practiced, and whether the practice could lead to success indicating virtì and resulting in survival of a prince. Moreover, I also contend that at the center of Machiavelli's separation of virtù from iniquity/ criminality/ wickedness is not the issue of amorality but that of the difference between cruelty and inhumanity as personal characteristics, and as an expression of virtù's amoral dimension. From the perspective of social philosophy, Machiavelli's exposition on the amorality of virtù should be understood as neither a conclusion nor a claim to an absolute truth, but as a door to a perspective that takes social relations as interdependent with the question of power, the latter being inherently amoral but inevitably shapes and is shaped in turn by the political dimension of morality. Simply put, from the discussion above I note that Machiavelli stands between social and political philosophy by focusing on the processual relationship between social behavior and political activities. We will again discuss Machiavelli's case for and against Agathocles, but for this part of our discussion, I note that for Kahn, ${ }^{32}$ the case of Agathocles was a rhetorical strategy that destabilized the idea of virtù for it to be aligned with the unstable political reality that

\footnotetext{
${ }^{31}$ Machiavelli, Prince, 92-95.

32 Victoria Kahn, "Virtù and the Example of Agathocles in Machiavelli's Prince," in Representations, 13 (1986), 63-83.

(C) 2016 Anthony Lawrence A. Borja

http://www.kritike.org/journal/issue 18/borja june2016.pdf

ISSN 1908-7330
}

(cc) BY-NC-ND 
Machiavelli grasped and presented. I further contend that this strategy was used to establish a distinction between the manifestation of raw personal character supported by non-political virtù (for Machiavelli, Agathocles had physical and mental virtì) and the manifestation of subjective conditions within the framework of political virtù. Hence, as would be elaborated later on, though the semblance of Agathocles' savagery could be found in Cesare Borgia's career, Machiavelli portrayed the latter as a man of virtù because his savagery was in accordance with political necessities and calculative prudence. ${ }^{33}$

Thus, for the first level of my analysis I propose a framework built upon four factors. The first two that could be placed under the category of agency are the subject with its necessary attributes, and virtù as a set of internalized principles and practices linked with the subject through contingent attributes. The last two under the category of object are Fortuna as the aggregate of all external concrete factors that are uncontrollable and unpredictable, and necessity as the form Fortuna takes in close temporal proximity to a subject. I would also like to note that in line with Althusser, it is in the absence of absolutes that Machiavelli grasped the eternal motion built on partiality. Hence, the focus of the second level of my analysis would be the internal relationship between Machiavelli's agency and object, specifically, the constant interplay, struggle, conflict, and engagement between virtù and Fortuna with the goal of achieving stability and durability.

\section{Virtù: A Dissection through Fortuna}

At this point I note that, for Machiavelli, though the Roman Empire was said to be founded on good Fortuna and a strong military, he deemed that "it ought to be perceived that where good discipline prevails there also will good order prevail, and good fortune rarely fails to follow in their train." ${ }^{34}$ From this statement of his perspective in dissecting the foundations of the Roman Empire, I deduced the notion of Fortuna being harnessed by acting upon other political actors through an imposition of discipline and the subsequent establishment of order (two results of virtù). Thus, moving to the particulars of virtù-Fortuna I argue that the internal relationship between these two can be defined in two ways. First, virtù is an imposition of a form (i.e., order, stability, and duration for a state) upon the matter of Fortuna, ${ }^{35}$ and second, the latter's contingent nature ensures that the process will be partial in completion and continuous or cyclical in character. Though I am

\footnotetext{
${ }^{33}$ Machiavelli, Prince, 26-30

${ }^{34}$ Machiavelli, Discourses, 105.

35 See Althusser, Machiavelli, 75-76; Pocock, Machiavellian Moment, 158-61. Their discussions however are focused on the New Prince and innovation.
} 
convinced about the validity of these interpretations, attempts to go down the ladder of generality through this path led to an overemphasis on certain dimensions of virtù and incomplete reconstructions of Machiavelli's analytical framework, that is, an emphasis on the new prince and a portrayal of Machiavelli as an early proponent of modern ideas ranging from constitutionalism and liberal republicanism ${ }^{36}$ to radical populism. ${ }^{37}$ For these reasons, I intend to provide a more detailed and systematic reconstruction of Machiavelli's analysis of virtù-Fortuna that would encompass both of these factors and their engagements with each other.

For my reconstruction, I argue that first, Fortuna could only be recognized as such via virtù as prudencel foresight. To elaborate, a person must have a relatively high degree of animo and mental capacity (memory, imagination, and ingenuity) in order for him to attain and further develop this aspect of virtù when he/she turns his/her attention to the outside world. Furthermore, without recognizing Fortuna through virtù as prudencel foresight, Machiavelli argued in his case against the princes of Italy that a subject is reduced to necessity and swept by it instead of preparing, resisting, harnessing, and adapting to it. The absence or eventual exhaustion of virtù as prudence/foresight ends with a subject's slavery to necessities outside his/her control and prediction, eventually losing power in the process; that is, in Machiavelli's medical terminology, he/she is shackled to the effects of a sickness that matured and grew worse because of a his/her shortsightedness. ${ }^{38}$ At this point, the internalization of Fortuna through virtù takes another step because of the inevitable impact of Fortuna's movements upon a subject. If virtù as prudencel foresight allows a subject to see the principles and patterns behind necessity (i.e., Fortuna), virtù as control (the will and capacity to attain and sustain control) allows him/her to target and act towards the specific concrete factors constituting Fortuna. Thus, through prudencelforesight, a subject recognizes problems and/or opportunities, and through control, he/she will act accordingly with more specific targets in sight.

Second, I note that for Machiavelli, the dimensions of virtù correspond to the characteristics of Fortuna because the former realizes itself only through the latter, that is, the opportunities and/or problems provided by nature and/or significant actors who are either directly or indirectly attached to the subject. If his/her necessary properties are lacking, virtù will

${ }^{36}$ Marcia L. Colish, "The Idea of Liberty in Machiavelli," in Journal of the History of Ideas 32 (1971), 323-50; Kocis, Machiavelli Redeemed, 128-63, 193-218; Pocock, Machiavellian Moment, 50652.

37 Althusser, Machiavelli, 62; John P. McCormick, "Machiavellian Democracy: Controlling Elites with Ferocious Populism," in The American Political Science Review, 95 (2001), 309-11

${ }^{38}$ Machiavelli, Prince, 12.

(C) 2016 Anthony Lawrence A. Borja

http://www.kritike.org/journal/issue 18/borja june2016.pdf

ISSN 1908-7330

(c) BY-NC-ND 
be deficient as was in Machiavelli's portrayal of King Louis XII of France. ${ }^{39}$ However, even if there is an alignment between inherent capacities and virtù, or a high degree of necessary properties in Fischer's terms, Machiavelli using the case of Cesare Borgia's fall, posited two interrelated arguments, namely, that virtù will never be absolute and that Fortuna could exploit any weakness. ${ }^{40}$ In summary, I contend that for Machiavelli, it is through the activities of others (through their failures, successes, expressions of virtù, or their lack of it) that a subject could manifest his own internalization of virtù, or in other words, if virtù is understood as a set of principles then its practice (as the result of its internalization and eventual expression) necessitates an other that will both qualify and facilitate it. Virtù, as Machiavelli's works suggests, can neither be analyzed nor practiced without an other, and this schema is central to his socio-political framework.

To illustrate this process of internalizing and expressing virtù, I reiterate that a relatively high degree of the necessary properties exposed by Fischer allows its bearer to be a worthy subject and see beyond necessity and recognize his goals (i.e., ambition) in relation to the dynamics of Fortuna. To be specific, along with an understanding of what he/she must face, a subject also gains an insight on how he/she could face Fortuna as the imposing figure of unpredictability and uncontrollability. Machiavelli sees in the subject, may it be princes or citizens, a synthesis of Fortuna's power with the will and struggle to resist, if not overcome it, through prudence and foresight on one hand, and the search, attainment, and maintenance of control on the other and one's self. Therefore, I contend that virtù as prudencelforesight corresponds with the constant motion of Fortuna, while virtù as control is concerned with shaping the behavior and/or character of its concrete factors. The former could be illustrated through Machiavelli's arguments on the need to predict causes and address future problems. For him, "when recognized in advance-a gift granted to prudent men only-illnesses appearing in a state are quickly healed; but when they are not recognized and are allowed to intensify so that everyone recognizes them, they can no longer be remedied." 41 Moreover, prudence/foresight also finds material via the careful study of history that Machiavelli advocated in both The Prince ${ }^{42}$ and Discourses ${ }^{43}$; that is, in Althusserian terms, prudence/foresight is about having a grasp of a present conjunction, understanding its possibilities, and studying similar conjunctions and conditions faced by one's predecessors.

${ }^{39}$ Ibid., $15-16$

${ }^{40}$ Ibid., 32.

${ }^{41}$ Ibid., 12.

${ }^{42}$ Ibid., 21-22, 58-60.

${ }^{43}$ Machiavelli, Discourses, 31-33.

(C) 2016 Anthony Lawrence A. Borja

http://www.kritike.org/journal/issue 18/borja june2016.pdf

ISSN 1908-7330

(cc) BY-NC-ND 


\section{VIRTÙ, FORTUNA, AND STATECRAFT}

For virtù as control, I contend that for Machiavelli, this dimension consists of the will, capacity, and struggle to determine one's own behavior and the behavior of targeted others. An illustration of this dimension is the need to determine the flow and benefit from the results of class conflict or the contradictions between the interests/goals and perspectives of the nobility and commoners, the former was portrayed by Machiavelli, as more devious, ambitious, and aggressive than the latter with more simple/ordinary goals tied to a more defensive behavior. ${ }^{44}$ For him "in every city these two diverse humors are found, which arise from desire neither to be commanded nor oppressed by the great, and the great desire to command and oppress the people." 45 Moreover, the latter sees themselves as equals to the prince, thus, they present numerous dangers to a prince's leadership especially if they are greedy and resistant, if not rebellious. ${ }^{46}$ Hence, with virtù as the search for and maintenance of control, a prince must impose upon these entities the identity of subjects by protecting the commoners through institutions (i.e., legal institutions that will protect the people and act as mediator between these two conflicting classes), and by making the rich/nobility realize that he could make, destroy, or replace them. ${ }^{47}$

Before moving on to its sub-dimensions, I note that first, virtù is anticipative and responsive, reflective of the expression of prudence in controlling. Second, its two primary dimensions (prudence/foresight and control) are inseparable though distinct from each other; that is, these two correspond to the ideal and practical aspects of human activity. Hence, these two should also be considered as categories that, once made to engage Fortuna in theorizing political practice, gain specificity in terms of other subdimensions that are either anticipative or responsive, resulting from the interaction between the two primary dimensions of virtù and the conditions laid down by Fortuna. Lastly, an underlying theme in Machiavelli's The Prince and Discourses is the absence of guarantees or a cosmic fate for political actors, and for this reason, he exposed how virtù could lead either to success or failure in relation to Fortuna's demands on the subject. I contend that through Althusser's notion of correspondence between Machiavelli's virtù and Fortuna, four secondary dimensions of the former's engagement with the latter could be deduced. Moreover, these four are expressions of the interdependence of the two primary dimensions, and of virtù's anticipative and responsive (aggressive and defensive) natures.

The first one is virtù as adaptation and three points could be made as an elaboration. First is that Machiavelli, in trying to explain the differences

\footnotetext{
${ }^{44}$ Machiavelli, Prince, 38-39.

45 Ibid., 39.

${ }^{46}$ Ibid., 38-41.

${ }^{47}$ Ibid., 74-75.
}

(C) 2016 Anthony Lawrence A. Borja

http://www.kritike.org/journal/issue 18/borja june2016.pdf

ISSN 1908-7330

(c) BY-NC-ND 
in the results of similar policies, argued that a prince's success or failure is partially determined by his capacity to cope with the times instead of being dependent on Fortuna. ${ }^{48}$ He stated that:

the prince who leans entirely on his fortune comes to ruin as it varies. I believe, further, that he is happy who adapts his mode of proceeding to the qualities of the times; and similarly, he is unhappy whose procedure is in disaccord with the times ... for if one governs himself with caution and patience, and the times and affairs turn in such a way that his government is good, he comes out happy; but if the times and affairs change, he is ruined because he does not change his mode of proceeding. ${ }^{49}$

Second is that, for Machiavelli, a prince must not only understand and recognize all possibilities brought in by Fortuna's motion (prudence/foresight), but also have the capacity and the will to make available and utilize all possible means for the preservation of power. ${ }^{50}$ He must be both a lion and a fox for the former is strong but lacks prudence, while the latter lacks strength but has keen senses, and must know how to use both law and force. ${ }^{51}$ Also, it is in this sub-dimension that we find the capacity to switch between anticipative and responsive mechanisms.

Lastly, Machiavelli expressed his distrust towards man's capacity for adaptation by pointing to a tendency for habits and inflexibility. ${ }^{52} \mathrm{He}$ argued that a man "cannot deviate from what nature inclines him to or also because, when one has always flourished by walking on one path, he cannot be persuaded to depart from it" 53 thus, leading to his eventual fall once external conditions change. I deduce two other possible interpretations of Machiavelli's perspective on adaptation, namely, that he posits a required "unnatural" effort from the part of a prince, or that Machiavelli simply gives the constant motion of politics (i.e., Fortuna) primacy over human efforts and their results. Although for the latter, I note that despite Fortuna's impenetrability, Machiavelli counseled man to always "hope and, since they hope, not to give up in whatever fortune and in whatever travail they may find themselves." 54

\footnotetext{
48 Machiavelli, Discourses, 239-240.

${ }^{49}$ Machiavelli, Prince, 99-100.

${ }^{50}$ Ibid., 68-69.

${ }^{51}$ Ibid., 69.

52 Ibid., 100-101.

53 Ibid., 100.

${ }^{54}$ Machiavelli, Discourses, 199.
} 
In relation to the first one, virtù as moral flexibility could be understood in several ways. First is that for Machiavelli amorality is an attribute based on a subject's understanding, albeit a negative one of human nature. This in turn facilitates his/her practice of prudence/foresight, specifically, his/her identification of the possible actions that others might take in relation to him/herself. To illustrate, Machiavelli argued that "a man who wants to make a profession of good in all regards must come to ruin among so many who are not good" and because of this a prince must "learn to be able not to be good, and to use this and not use it according to necessity." 55 Second, moral flexibility allows a subject to effectively practice adaptation by having control over the direction of one's own actions instead of it being tied to, if not weighed down by, the moral standards of others. Reflective of the distinction made earlier between Fortuna and necessity, as well as the human component of the former, another way to interpret this dimension of virtù is to recognize the necessity for a subject to appear as an embodiment of publicly accepted virtues. Behind this need is the common people whose power and interests a prince must deal with. Chapters 15 until 19 of The Prince were dedicated to this dimension of virtù and I would like to highlight two points. First is that for Machiavelli, a prince must be prudent in adapting the distinction between vice and virtue for the sake of sustaining control. A prince must appear to be the bearer of virtues accepted by the public, 56 albeit "one should not care about incurring the fame of those vices without which it is difficult to save one's state." 57 However, he must avoid hatred emanating from acts of terror or vices offending the private sphere of others. Second, in his discussion on fear and love, Machiavelli emphasized the need to sustain control over affected others, first by relying on fear as something one controls, and second by emphasizing the need to avoid hatred. Machiavelli ${ }^{58}$ illustrated that love, unlike fear, is under the control of the one giving it and that hatred, unlike fear, is an emotion that is controlled and could be utilized as a resource by the affected other. The latter could also be illustrated by his warning that the memory of freedom and liberties lost could be used to stir up hatred and disorder in a newly conquered domain. ${ }^{59}$

Lastly, in relation to virtù as adaptation, moral flexibility allows a subject to utilize all possible means to attain and sustain power in the context of changing socio-political conditions. For Machiavelli, a subject must act in accordance with two factors, namely, attaining and sustaining power as a primary goal, and the inevitable attachment of public opinion with the

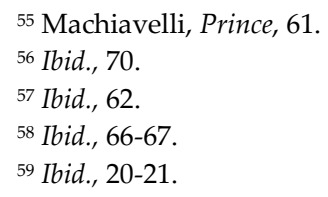

(C) 2016 Anthony Lawrence A. Borja http://www.kritike.org/journal/issue 18/borja june2016.pdf ISSN 1908-7330 
effectiveness of means employed. Moreover, I reiterate that for Machiavelli the use of force (violence and cruelty) must appeal to the idea of public good (i.e., stability, order, and security) as was in the case of Remirro d'Orco and the need to be swift and decisive in inflicting violence upon the acquisition of power. ${ }^{60}$ Also, for Machiavelli, force must be replaced by institutions that would safeguard the public good and sustain the power attained through force and/or cunning. ${ }^{61}$ In summary, these interpretations could be subsumed under the notion that virtù as adaptation and moral flexibility allows a subject to be actively flexible in responding to an event or seizing an opportunity it offers. Moreover, these two allow a subject to recognize boundaries that would ensure that public opinion, as a component of Fortuna, remains under his control, thus, depriving opponents of any moral justification for conspiracies. ${ }^{62}$

Virtù as the search for glory ${ }^{63}$ embodies Machiavelli's intimate attachment to the idea of a new prince, ${ }^{64}$ his supposed adoption of an archaic moral code of emulating excellence, ${ }^{65}$ and the anticipative aspect of virtù. For my part, I highlight that the search for glory and prestige should be understood as a form of control over the nobility and the commoners, and a policy emerging from an anticipatory sense of prudence. Machiavelli, using the case of King Ferdinand of Aragon, stated that as an upstart, great and ambitious campaigns justified by religious claims allowed him not only to give proof to his abilities, but also to express virtù as control over public opinion and the activities of spectators by imposing a sense of predictability over one's subjects, first by providing a stimulus to public opinion instead of allowing it to be absolutely spontaneous, and second by giving a direction to the produce of one's subjects.

Lastly, virtù as audacity, ${ }^{66}$ as an anticipative sub-dimension like the previous one, represents Machiavelli's attempt to posit a way to penetrate Fortuna by advocating an aggressive stance (i.e., adopting an anticipatory

${ }^{60}$ Ibid., 29, 39-40.

${ }^{61}$ Ibid., 82.

${ }^{62}$ Ibid., $72-73$.

${ }^{63}$ Ibid., 87-91.

${ }^{64}$ Althusser, Machiavelli, 53-80; Breiner, “Machiavelli's New Prince," 83-89.

65 See Terence Ball, "The Picaresque Prince: Reflections On Machiavelli and Moral Change," in Political Theory, 12 (1984), 521-36. I note that, in isolating the concept of virtù for analysis, he argued that neither Machiavelli nor his prince was amoral. Instead, similar to the character of Don Quixote, Machiavelli's prince embodied a moral code of heroism through emulation.

${ }^{66}$ See Tarlton, "Action for Action's Sake," 123-36 who highlighted the audacious improvisations required from a prince. Though I disagree with his reduction of virtù into audacity, I note that though Fortuna could require this mode of action, its unpredictable movements for Machiavelli could also require the contrary, thus, necessitating a more encompassing understanding of how a virtuoso should behave. 
strategy and offensive tactics). This was also attached by Machiavelli to impetuosity as a necessary attribute inherent in actors like Julius $\mathrm{II}^{67}$ and the Gauls, ${ }^{68}$ but it was in the former and in the Romans that such an attribute became a virtù; that is, Julius used it to avoid a political impasse while the Romans used it to complement their virtù as prudencelforesight. ${ }^{69}$ Now this alignment was due to the fact that Machiavelli was convinced "that it is better to be impetuous than cautious, because fortune is a woman ... And one sees that she lets herself be won more by the impetuous than by those who proceed coldly. And so always, like a woman, she is the friend of the young, because they ... command her with more audacity."70 This stance was due to his positive interpretation of Fortuna's inherent uncertainties as the bearer of both opportunities and difficulties, tied with his disapproval of defeatist and dependent policies. ${ }^{71}$ Moreover, virtù as audacity also satisfies the lion that a prince must have as a part of his overall adaptability, that is, to use the ways of man and beast, and to be both a lion and a fox. An illustration of this is Machiavelli's brief account of how Alexander VI, in trying to gain power and territory in the Italian peninsula, facilitated the entry of the French that subsequently destroyed an already fragile balance of power, thereby giving himself the opportunity to utilize French forces to seize territories in the context of an aggravated flux..$^{72}$ I see this as Machiavelli's illustration of a subject's capacity not only to survive a wave of destruction but to initiate and benefit from it, or in other words, invoke the destructive and usually equalizing power of Fortuna instead of merely waiting for it.

In summary, the relationship between Fortuna and virtù is founded on the latter as a set of principles and practices that allows internal capacities (necessary properties) to be used effectively for the search and sustenance of power, and on the former as an aggregate of both relatively static (i.e., nature/geography) and constantly moving (ex. the activities of others) factors that serves as the objects of virtù as control, and the source of material (i.e., problems/worries and opportunities) for virtù as prudence. Virtù is internalized through a study of history, that is, the patterns defining the rise and fall of states, and the actions of great men within their respective environments. However, its existence is not solely based on such principles and practices. Virtù is also expressed as a combination of both responsive (as adaptation and moral flexibility) and anticipative practices (as the search for

${ }^{67}$ Ibid., 367-69; Machiavelli, Discourses, 240.

${ }_{68}$ Machiavelli, Discourses, 292-293.

${ }^{69}$ Machiavelli, Prince, 11-13.

70 Ibid., 101; See Machiavelli, Discourses, 304-305.

${ }^{71}$ See Timothy Lukes, "Lionizing Machiavelli," in American Political Science Review, 95 (1984), 562-75 for a review of works that re-claimed and highlighted the Lion of Machiavelli's Prince.

${ }^{72}$ Machiavelli, Prince, 27.

(C) 2016 Anthony Lawrence A. Borja

http://www.kritike.org/journal/issue 18/borja june2016.pdf

ISSN 1908-7330

(cc) BY-NC-ND 
glory and audacity), and in these modes we find a reflection of the fickle nature of Fortuna or, to be specific, the impact of the socio-political environment (i.e., the absence of guarantees and absolute security, and the constancy of change) on a subject's modes of expressing virtù (i.e., engagements with Fortuna and its concrete components).

\section{Virtù as Autonomy}

I conclude this paper by synthesizing all the dimensions discussed above into virtù as autonomy, or the will and capacity to attain and sustain selfdetermination through both anticipative and responsive means. This could be illustrated in two ways - first, through Machiavelli's arguments on militias and the strength of principalities and second, through his arguments on new princes and the need to deal with class conflict. First, for Machiavelli, mercenaries and their commanders are dangerous not only because of their adverse practices but also because their loyalty lies not with the prince but with money, and their commanders, if they have both military and political virtù, could easily depose their employers. ${ }^{73}$ However, in using loyalty and military virtù as standards, he concluded that auxiliaries or soldiers borrowed from a foreign power "are much more dangerous than mercenary arms. For with these, ruin is accomplished; they are all united, all resolved to obey someone else."74 Dependence on mercenaries and/or auxiliaries embodies the lack of virtù that caused the subjugation of the Italian peninsula by foreigners; mercenaries are anti-thetical to military prowess while the usage of auxiliaries is a step towards being under the control of a foreign entity. Hence, for Machiavelli, virtù as autonomy will eventually lead a subject towards the use of militias because "without its own arms, no principality is secure; indeed, it is wholly obliged to fortune since it does not have virtue to defend itself in adversity." 75 In relation to this, virtù as autonomy was also implied in Machiavelli's usage of self-sufficiency as an indicator of strength for principalities. ${ }^{76}$ Furthermore, Machiavelli considered a state as strong if it has enough resources and military capacity that a leader with virtù could transform into cohesion during a crisis. In summary, a subject's search for autonomy must manifest itself in terms of resources and control over one's means of coercion.

Thus, upon its acquisition and to address the questions of durability and stability, power must be secured through institutions (laws and policies) that are either inherited or must be built upon the ashes of an old regime.

\footnotetext{
${ }^{73}$ Ibid., 48-49.

74 Ibid., 55.

75 Ibid., 57.

${ }^{76}$ Ibid., 42-3.
} 
Applied to both princes and republics is Machiavelli's emphasis on the need for institutions that will make them distinct from social/class forces; a prince must strive to be autonomous from the nobility and the commoners, while a republic must be built and sustained by neither of these classes but the results of their constant conflicts. ${ }^{77}$ Machiavelli took the existence of these classes as a given or a permanent fixture that provides material for the forms imposed by the virtù of princes and leading citizens. ${ }^{78}$ An example of this is Machiavelli's narration of how the office of Tribune emerged out of the conflict between the nobility and the commoners. Tribunes eventually contributed to the stability of the Roman Republic because it served as the institutionalized power of the commoners that kept a balance between these two classes, and mediated between the commoners and the institutionalized power of the nobility embodied by the senate and the consuls. ${ }^{79}$ For a prince, on the other hand, I note two of Machiavelli's points elaborated in Chapters 9 and 19 of The Prince. First is that though the people are much less dangerous than the nobility, Machiavelli made it clear that a prince could and should never depend on either one..$^{80}$

Second, for Machiavelli, domestic conflict among different sectors is a given, and from it a state will always be vulnerable to disruptions that will threaten the stability, duration, and autonomy of princes and republics. Therefore, placed in the context of Fortuna, virtù as autonomy sums up what a republic or prince should strive for and maintain through virtù in general. Moreover, a lapse in the sub-dimensions of virtù will eventually end up in Fortuna subjugating a subject's autonomy; that is, a gap in one's control over others or a relapse into short-sightedness are, for Machiavelli, opportunities for Fortuna to sweep princes and republics away and expose them to an uncontrollable and unpredictable deluge driven by the will and virtù of others.

\section{Conclusion: Machiavelli and the Struggle for Autonomy}

In placing the different dimensions of virtù in the context of Fortuna as founded upon nature and the virtù/non-virtù of others, I contend that Machiavelli's contribution to the modern concept of politics is the notion of the eternal struggle for autonomy as fundamental to statecraft. I argue that,

77 Machiavelli, Discourses, 15-26. Chapters 3 to 7 are preliminary examinations of Machiavelli on the Roman Republic that examined how domestic conflict could result in the sustenance of liberty and how the government, in order to achieve this result, should stand above classes through representation on one hand, and separating such classes through mediating institutions on the other.

78 Machiavelli, Prince, 38-39.

${ }^{79}$ Machiavelli, Discourses, 15-17.

${ }^{80}$ Machiavelli, Prince, 40-42.

(C) 2016 Anthony Lawrence A. Borja

http://www.kritike.org/journal/issue 18/borja june2016.pdf

ISSN 1908-7330

(c) $\mathrm{BY}-\mathrm{NC}-\mathrm{ND}$ 
for Machiavelli, this endeavor is comparable not to the act of stopping a river but to exertions to remain afloat or control its direction. Furthermore, with Fortuna as the overarching term used to tackle the grave and aleatory character of the aggregate effects of these others' activities and engagements with the subject and with each other, Machiavelli concluded that a subject's drive and capacity to attain and sustain self-determination will always be at the expense of others and for this reason such others will either surrender or resist. Autonomy, control, and predictability are both goals of virtù and results of others' reaction to its expressions by a dominant subject, but this virtù itself is framed in accordance to a grasp of control and predictability as necessities posited by the nature of Fortuna.

Thus, I conclude that for Machiavelli, the eternal struggle for autonomy is partially based on Fortuna as the constancy of uncertainty (i.e., the unpredictability of the actions of others in pursuing heterogeneous interests through differing capacities) and as the embodiment of a mélange of uncontrolled set of social relations with direct or indirect effects upon a subject's pursuit of his/her interests. For future inquiries, by establishing the centrality of autonomy in the dialectical relationship between virtù and Fortuna and recognizing the republican and democratic leanings of Machiavelli (or at least ideals that can be extracted from his works), this study would like to posit the possibility of conceptualizing freedom as a virtuoso struggle that can be both collective and individual but necessarily social and to an extent aleatory. Simply put, future inquiries can address how Machiavelli's conceptualization of virtù and Fortuna can inform us about the sociopolitical dimension of freedom.

Department of Political Science, De La Salle University, Manila, Philippines

\section{References}

Althusser, Louis, Machiavelli and Us, trans. by Gregory Elliot (London: Verso, 1999).

Ball, Terence, "The Picaresque Prince: Reflections On Machiavelli and Moral Change," in Political Theory, 12 (1984).

Breiner, Peter, "Machiavelli's 'New Prince' and the Primordial Moment of Acquisition," in Political Theory, 36 (2008).

Colish, Marcia L., "The Idea of Liberty in Machiavelli," in Journal of the History of Ideas, 32 (1971).

Fischer, Markus, "Machiavelli's Political Psychology," in The Review of Politics 59 (1997). 


\section{VIRTÙ, FORTUNA, AND STATECRAFT}

Kahn, Victoria, "Virtù and the Example of Agathocles in Machiavelli's Prince," in Representations, 13 (1986).

Kocis, Robert A., Machiavelli Redeemed: Retrieving his Humanist Perspectives on Equality, Power, and Glory (Bethlehem: Lehigh University Press, 1998).

Lukes, Timothy J., "Fortune Comes of Age in Machiavelli's Literary Works," in Sixteenth Century Journal, 11 (1980).

Machiavelli, Niccolò, Discourses on Livy, trans. by Harvey C. Mansfield (Chicago: Chicago University Press, 1996).

The Letters of Machiavelli: A Selection, trans. by Allan Gilbert (Chicago: The University of Chicago Press, 1961).

The Prince, $2^{\text {nd }}$ Edition, trans. by Harvey C. Mansfield (Chicago: Chicago University Press, 1998).

Mansfield, Harvey C., "On the Impersonality of the Modern State: A Comment on Machiavelli's Use of Stato," in The American Political Science Review, 77 (1983).

McCormick, John P., "Machiavellian Democracy: Controlling Elites with Ferocious Populism," in The American Political Science Review, 95 (2001).

Newell, W.R., “How Original Is Machiavelli? A Consideration of Skinner's Interpretation of Virtue and Fortune," in Political Theory, 15 (1987).

Pocock, John G.A., The Machiavellian Moment: Florentine Political Thought and the Atlantic Republican Tradition (Princeton: Princeton University Press, 1975).

Tarlton, Charles D., “Azioni in modo l'una dall'altra: Action for Action's Sake in Machiavelli's The Prince," in History of European Ideas, 29 (2003).

Viroli, Maurizio, "The Revolution in the Concept of Politics," in Political Theory, 20 (1992).

Wood, Neal, "Machiavelli's Concept of Virtù Reconsidered," in Political Studies, 15 (1967).

(C) 2016 Anthony Lawrence A. Borja

http://www.kritike.org/journal/issue 18/borja june2016.pdf

ISSN 1908-7330

(c) $)$ BY-NC-ND 